\title{
Logic to Electronics: A Teaching Unit for Elementary Students
}

\author{
Elaine M. Cooney, Arlene Mueller \\ Indiana University Purdue University Indianapolis / \\ School District of Affton, Missouri
}

\section{Rational}

Today's primary age school children feel very comfortable using electronic equipment. But often they are not even exposed to simple electric circuits, let alone digital electronic circuits, until much later in their education. Too often, by that time, their natural inquisitiveness has faded and fear of difficult challenges is overactive. Because third grade students are comfortable with visual logic problems and verbal logic problems, they are ready to play with and thereby learn about electronic logic.

The challenge is to make this technology accessible both conceptually and physically to elementary students. The children are introduced to the concepts of combinational logic using visual and verbal logic. The hardware is made available by using a circuit board designed for this project.

\section{Purpose and Objectives}

The purpose of this project is to teach second and third grade children simple electrical circuitry and how it is related to digital logic circuits. With this knowledge, the children can develop projects such as interactive bulletin boards and simple robots. There are three main objectives:

1. Provoke curiosity about electricity by allowing the children to play with wires, batteries, bulbs, and switches.

2. Show the children how to improvise and engineer solutions to authentic problems using common materials.

3. Teach the children how to record as they observe, question, test, analyze, predict, synthesize, and evaluate during the course of their investigations.

\section{Preliminary Activities}

The children need to learn to attend to detail. As early as kindergarten, the children begin participating in activities designed to strengthen the skills needed for deductive reasoning, visual logic, and verbal logic. Activities and lessons are available from a variety of sources ${ }^{1,2,3}$.

A current emphasis in education is integrating all areas of the curriculum. The logic problems 
are used to enrich both reading and math because they interrelate the skills of critical reading and the use of mathematical symbols in logic analysis. Each puzzle has three parts. The introduction sets the background and helps the students become familiar with the elements of the puzzle. The clues relate all of the components and provide a basis for the logical linking together of the pieces of information, thereby allowing students to make deductions that will lead to the solution. The grid is the work space for sorting, eliminating and associating the clues. Every square on the grid represents a possible answer. By eliminating possibilities, one is finally left with only one choice per row or column. The one square that is not eliminated is the one correct solution. When this is done for every row and column, the puzzle is completed. Students find that it is necessary to look not only at each clue individually, but also to look at the clues in relation to one another in order to derive as much information as possible.

Visual logic cards have colorful pictures of patterns, grids, maps and charts representing puzzling problems. The trick is to correctly read and understand the directions. Quite often the children are stumped because they read the directions incorrectly and as soon as they are asked to read it aloud, the "ah-hah" happens. Sometimes there are multiple directions or answers and the children need to reprogram their thinking which tells them one answer is enough. Sometimes the puzzle is simple and the students make it harder because of their presuppositions. The main point of this work is to make the student focus on exactly what is being asked and what information is given.

The concepts of atoms, electrons, and electricity are new to most third graders. By performing a wide range of safe, easy experiments using simple household items, the children observe and experiment with electricity at work. Students make "wire" using aluminum foil (the conductor) and masking tape (the insulation). With this "wire" they construct simple circuits using batteries as power supplies, Christmas tree lights as impedances, and construction paper to hold it all together. (Activities and lessons are taken from reference 4 and other sources).

Circuit Board

The circuit board is designed for flexibility and ease of use. This allows the students to easily create a variety of digital circuits. All the biasing of the digital integrated circuits (ICs), light emitting diodes (LEDs), and switches is completed on the printed circuit board, so students need only wire their logic designs. (Figure 1). The final board size is approximately 1.75 " by $8.35 "$.

On each circuit board (Figure 2) are four 14 pin IC sockets to hold the logic integrated circuits. $\mathrm{V}_{\mathrm{cc}}$ and ground are connected on the board.

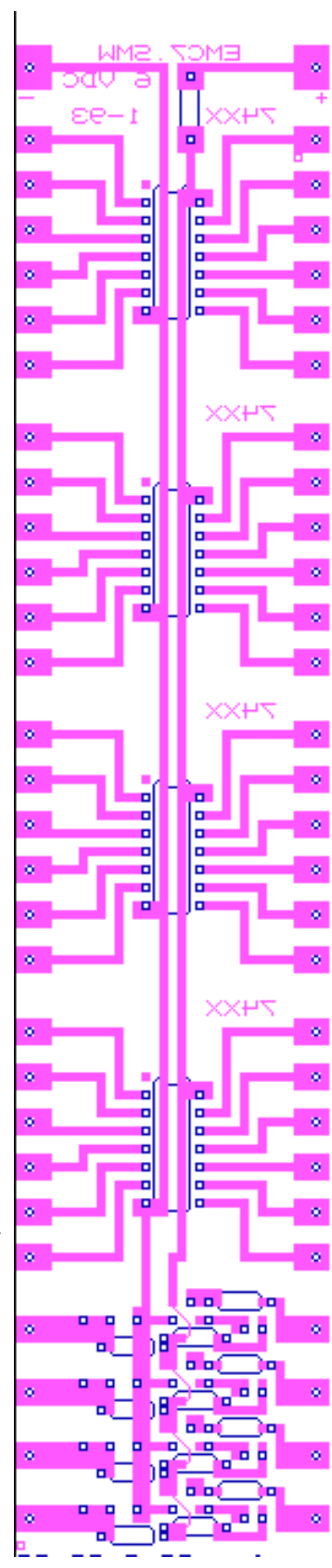

Figure 1: Board Layout 

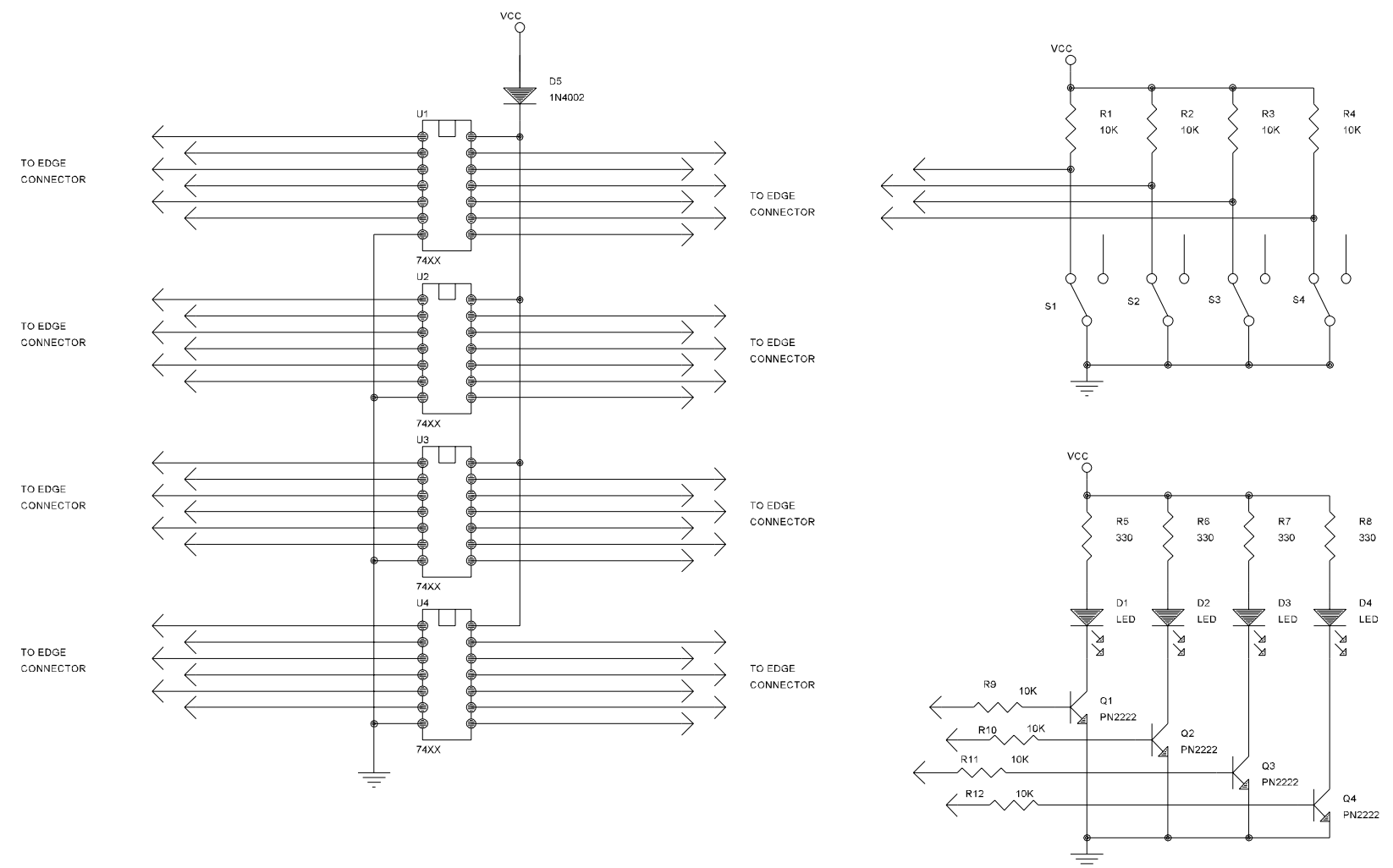

Figure 2: Schematic

Four LEDs are available, complete with driver transistors and current limiting resistors. Also on the board are four switches with pull-up resistors wired to $\mathrm{V}_{\mathrm{cc}}$ and ground to be TTL compatible. The circuit is powered with four "D" cells. A diode in series with the battery supply drops $\mathrm{V}_{\mathrm{cc}}$ to approximately $5 \mathrm{~V}$ and prevents harm to the circuit if the battery pack is hooked up backwards.

A great deal of thought went into determining how the students could connect to the components. Alligator clip leads were selected for reasons of safety (the clips are shielded, leaving little area of "live" wire exposed) and ease of use (no tools or special equipment needed). At first the clips were connected to pads at the edge of the circuit board, but the clips would wiggle and short together. Further, only one clip would fit on a pad, limiting the number of connections that could be made. Then it was suggested that machine screws be put through the pads and used to hold the clip leads. (Figure 3). The clips were less likely to short together, and there was room for two or three clips on each screw. In addition, the screws stand up higher than all the other components, thus protecting them

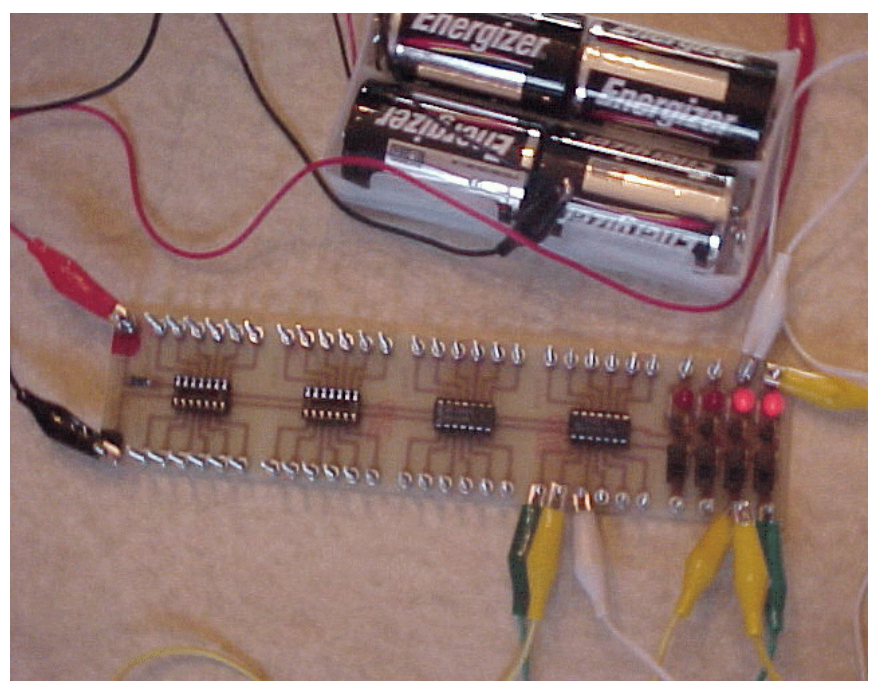

Figure 3: Connectors 
during handling and storage.

Table 1 contains a parts list for the circuit boards. Twenty five boards were fabricated and populated for under $\$ 500$. The funding for this project came from a South Western Bell Telephone Classroom Grant awarded to the School District of Affton, Missouri.

Digital Electronics Exercises

Armed with the readiness learning with verbal logic and electricity, the third graders are now ready to be introduced to the circuit board. They first experiment with the board and power source to make the lights (LEDs) and switches work together. When they can draw the circuit for the switches and lights, they are given a logic gate and its pinout, or schematic drawing. By experimentation they discover how the gate changes the operation of the switch and lite, and compare this to the verbal logic studied earlier. As students progress, they are able to use different gates and

\begin{tabular}{|c|c|c|c|c|c|}
\hline ITEM & DESCRIPTION & $\begin{array}{l}\# / \\
\text { BOARD }\end{array}$ & $\begin{array}{l}\text { TOTAL } \\
\text { PURCH. }\end{array}$ & $\begin{array}{l}\text { PRICE } \\
\text { EA. }\end{array}$ & $\begin{array}{l}\text { TOTAL } \\
(\$)\end{array}$ \\
\hline $\begin{array}{l}\text { DIODE } \\
1 \mathrm{~N} 4001\end{array}$ & Circuit protection & 1 & 30 & $\$ 0.07$ & $\$ 2.10$ \\
\hline $\begin{array}{l}\text { INVERTERS } \\
7404\end{array}$ & $\begin{array}{l}\text { Logic inverter } \\
\text { integrated circuit }\end{array}$ & 1 or 2 & 30 & $\$ 0.19$ & $\$ 5.70$ \\
\hline $\begin{array}{l}\text { AND GATES } \\
7408\end{array}$ & $\begin{array}{l}\text { Quad 2-input AND } \\
\text { integrated circuit }\end{array}$ & 1 or 2 & 30 & $\$ 0.19$ & $\$ 5.70$ \\
\hline $\begin{array}{l}\text { OR GATES } \\
7432\end{array}$ & $\begin{array}{l}\text { Quad 2-input OR } \\
\text { integrated circuit }\end{array}$ & 1 or 2 & 30 & $\$ 0.19$ & $\$ 5.70$ \\
\hline $\begin{array}{l}\text { AND GATES } \\
7421\end{array}$ & $\begin{array}{l}\text { Dual 4-input AND } \\
\text { integrated circuit }\end{array}$ & 1 or 2 & 30 & $\$ 0.29$ & $\$ 8.70$ \\
\hline $\begin{array}{l}\text { TRANSISTOR } \\
\text { PN2222 }\end{array}$ & LED driver & 4 & 100 & $\$ 0.08$ & $\$ 8.00$ \\
\hline $\begin{array}{l}\text { RESISTOR } \\
10 \mathrm{~K} \text {-ohm }\end{array}$ & $\begin{array}{l}\text { Pull up and current } \\
\text { limiting }\end{array}$ & 8 & 200 & $1.95 / C$ & $\$ 3.90$ \\
\hline $\begin{array}{l}\text { RESISTOR } \\
\text { 330-ohm }\end{array}$ & $\begin{array}{l}\text { Pull up and current } \\
\text { limiting }\end{array}$ & 4 & 100 & $1.95 / C$ & $\$ 1.95$ \\
\hline LED & Indicating & 4 & 100 & $\$ 0.07$ & $\$ 7.00$ \\
\hline $\begin{array}{l}\text { SOCKET } \\
14 \mathrm{PIN}\end{array}$ & Holds ICs in board & 4 & 100 & $10.37 / C$ & $\$ 10.37$ \\
\hline SWITCH & Sub-miniature slide & 4 & 100 & $\$ 0.26$ & $\$ 26.00$ \\
\hline $\begin{array}{l}\text { BATTERY } \\
\text { HOLDER }\end{array}$ & $\begin{array}{l}\text { Holds } 4 \text { "D" cells in } \\
\text { series }\end{array}$ & 1 & 20 & $\$ 2.55$ & $\$ 51.00$ \\
\hline $\begin{array}{l}\text { ALLIGATOR } \\
\text { CLIPS }\end{array}$ & $\begin{array}{l}\text { Circuit assembly } \\
\text { (10 per pack) }\end{array}$ & $\begin{array}{r}2 \\
\text { (packs) } \\
\end{array}$ & 40 & $\$ 2.49$ & $\$ 99.60$ \\
\hline SCREWS 3/4" & Circuit connections & 58 & 2000 & $17.65 / \mathrm{M}$ & $\$ 35.30$ \\
\hline NUTS & $\begin{array}{l}\text { Hold screws in } \\
\text { place }\end{array}$ & 116 & 3000 & $6.95 / \mathrm{M}$ & $\$ 20.85$ \\
\hline \multirow[t]{3}{*}{ PC BOARD } & & 1 & 30 & & $\$ 172.50$ \\
\hline & MATERIAL & & 30 & $\$ 3.75$ & \\
\hline & $\begin{array}{l}\text { DRILL } \\
\text { PROGRAMMING }\end{array}$ & & 1 & $\$ 25.00$ & \\
\hline
\end{tabular}
explore combinational logic.

More advanced students can apply this knowledge to interactive bulletin boards or simple "toys" that they create. When one student desired to use more than four ICs, he discovered he could cascade boards to gain access to additional sockets, switches, and lights.

\section{Conclusion}

The primary age child is competent in the use of electronic devices and demonstrates a natural curiosity with how things work. The circuit board presented allows the use of logic gates and resistors in simple circuits as a contemporary adaptation of the whistle and bell electric circuits studied in past decades. 


\section{Acknowledgments}

The authors wish to express their thanks to Mr. James Cowan for his many insights and help in laying out and building the circuit boards.

\section{References}

$1 \quad$ Visual Thinking, set A, Dale Seymour Publication, P.O. Box 10888, Palo Alto, CA 94303.

2 Logic in Easy Steps, books 1-4, Midwest Publications Co. Inc., P.O. Box 448, Pacific Grove, CA 939500448 .

3 Connections, Introductory-Beginning. Dandy Lion Publications, San Luis Obispo, CA.

4 Electricity \#32, Tops Learning Systems, 10970 S. Mulino Rd., Canby, Oregon 97013.

\section{ELAINE M. COONEY}

Elaine Cooney is an Associate Professor of Electrical Engineering Technology in the Purdue School of Engineering and Technology at Indiana University Purdue University Indianapolis. She received her Bachelors of Electrical Engineering from GMI Engineering and Management Institute and her Masters of Electrical Engineering from Purdue University. Her areas of interest include analog circuits and electronics manufacturing.

\section{ARLENE CHASE MUELLER}

Arlene Mueller is the Director of Gifted Education for the School District of Affton, Missouri. She has her Masters of Education from Indiana University of Pennsylvania with additional graduate hours in psychometrics and the education of gifted children. Her best loved activity is being the parent and teacher of gifted children. 